\title{
Review of subcontracting practice in construction industry.
}

\begin{abstract}
Great numbers of traders from different specialisation makes construction industry is a complicated and unique industry. To overcome the demand on special expertise, advanced equipment, and huge investment cost, letting out work to subcontractors has been a norm in construction industry. Nevertheless, large presence of subcontracting poses challenges to contractors, client and their project management teams to manage such a large, diverse and fragmented group of subcontractors. Success of a construction project is essentially depending on the ability of general contractor to select the appropriate subcontractor during bidding process, and the sufficient management of subcontractor during construction. This paper served as a summary of literature review done on types of subcontractor, problems generated by subcontractor, and current proposed methods to enhance the subcontracting practice.
\end{abstract}

Keyword: Subcontractors; Construction; Construction industry. 